\section{Cooperative Binding Model}

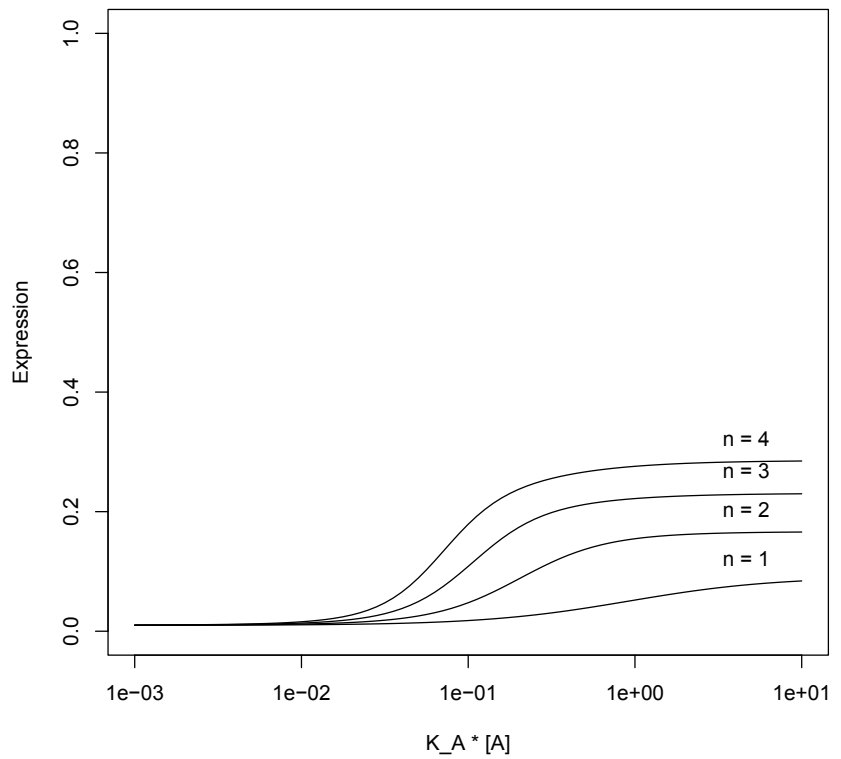

Multiplicative Activation Model

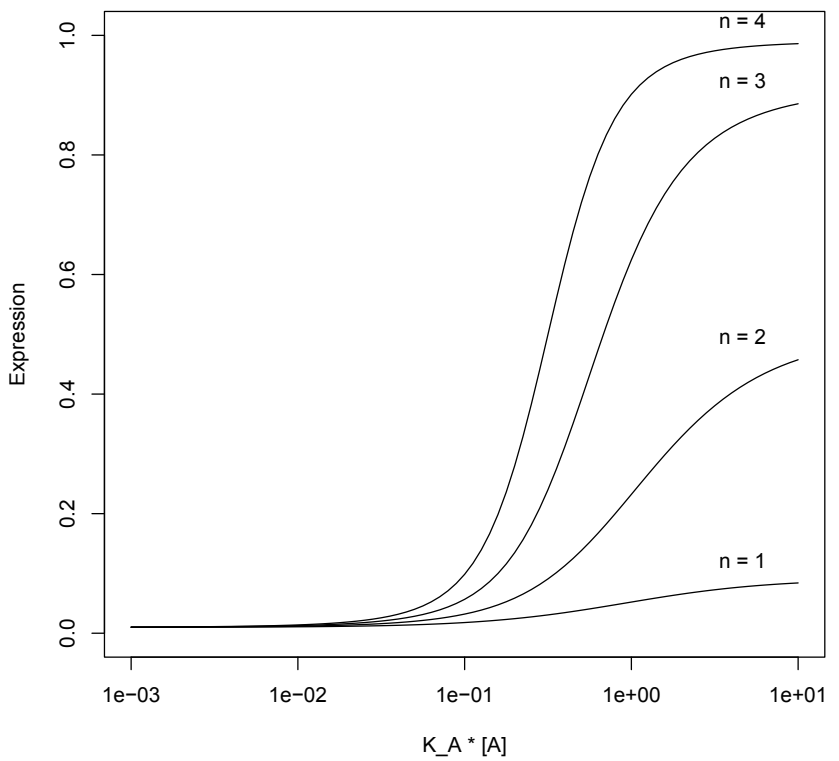

